Check for updates

Cite this: RSC Adv., 2019, 9, 753

Received 7th August 2018

Accepted 18th December 2018

DOI: $10.1039 / \mathrm{c} 8 \mathrm{ra06647g}$

rsc.li/rsc-advances

\section{Experimental and theoretical investigation of intramolecular cooperativity in cyclic benzene trimer motif $\uparrow$}

\author{
Chakka Kiran Kumar, $\mathbb{D} \ddagger^{\mathrm{a}}$ Shankar Deval Sathiyashivan, $\ddagger^{\mathrm{b}}$ Dhanraj T. Masram, ${ }^{\text {tb }}$ \\ K. V. Jovan Jose*a and Malaichamy Sathiyendiran (iD *a
}

A series of new symmetrical tripodal molecules $1 a-4 b$ with a central benzene scaffold substituted with methyl/ethyl groups and three benzimidazolyl units having a bithiophene/biphenyl/5-alkylthiophene motif at the 2-position via a $-\mathrm{CH}_{2}$ - unit were synthesized and characterized by elemental analysis, HRMS, and NMR spectroscopy. NMR spectral data reveal that all molecules adopt a cyclic benzene trimer (CBT) using three benzimidazolyl units. Intramolecular cooperative edge-to-face $\mathrm{C}-\mathrm{H} \cdots \pi$ interactions stabilize the CBT motif in solution and are strong in ethyl substituted molecules (1b-4b) compared to methyl substituted (1a-4a) ones. However, the strength of the CBT unit in the tripodal molecule is independent of the length of the substituent at the 2-position of the benzimidazolyl unit. The relative ${ }^{1} \mathrm{H}$ NMR chemical shift calculated at the MPW1PW91/6-311+G(d,p) level of theory corroborates the experimental values, and the calculations predict the distribution of the structures into syn isomers. The relative change in the NMR chemical shift is justified by the relative change in the magnitude of the $(3,+3)$ critical point $(C P)$ in the molecular electrostatic potential (MESP) topography. Also, a linear correlation of the intramolecular $\mathrm{C}-\mathrm{H} \cdots \pi$ interactions evaluated at $\mathrm{M} 062 \mathrm{X} / 6-311+\mathrm{G}(\mathrm{d}, \mathrm{p})$ with the relative NMR chemical shift suggest the latter as a measure of intramolecular cooperativity.

\section{Introduction}

Cooperative noncovalent interactions are vital for determining the structure and properties of molecules and materials., ${ }^{\mathbf{1 , 2}}$ Among the several interactions, $\mathrm{O}-\mathrm{H} \cdots \mathrm{O}, \mathrm{O}-\mathrm{H} \cdots \mathrm{N}, \mathrm{N}-\mathrm{H} \cdots \mathrm{N}, \mathrm{N}-$ $\mathrm{H} \cdots \mathrm{O}, \mathrm{C}-\mathrm{H} \cdots \mathrm{O}, \mathrm{C}-\mathrm{H} \cdots \pi$ hydrogen bonding interactions and $\pi \cdots \pi$ aromatic stacking interactions, cooperative edge-to-face $\mathrm{C}-\mathrm{H} \cdots \pi$ interactions between the aromatic units provide a significant contribution in stabilizing molecular structure. ${ }^{3}$ The cyclic benzene trimer (CBT) motif, i.e., three benzene units arranged in a cyclic manner, is the smallest cyclic cluster stabilized through cooperative $\mathrm{C}-\mathrm{H} \cdots \pi$ interactions in various aromatic clusters and is the basic building unit for higher order aromatic clusters. ${ }^{\mathbf{1 , 4}}$ Due to its importance, the cooperative edge-to-face $\mathrm{C}-\mathrm{H} \cdots \pi$ interactions in the CBT motif are studied theoretically. ${ }^{5}$ The non-additive behavior of the $\mathrm{C}-\mathrm{H} \cdots \pi$ interactions within CBT motifs adds to the intramolecular cooperativity. ${ }^{6}$ Several complexes possessing CBT motif in the solid

\footnotetext{
${ }^{a}$ School of Chemistry, University of Hyderabad, India. E-mail: msathi@uohyd.ac.in; jovanjose@uohyd.ac.in

${ }^{b}$ Department of Chemistry, University of Delhi, India. E-mail: dtmasram@chemistry. du.ac.in

$\dagger$ Electronic supplementary information (ESI) available: NMR spectra and theoretical data of $\mathrm{L}^{1}-\mathrm{L}^{4}$ and 1a-4b. See DOI: 10.1039/c8ra06647g

\$ Both authors contributed equally.
}

state are not noticed or reported. However, reports on molecules possessing the CBT motif both in solution and the solid state has started to appear recently. ${ }^{7}$ We found a simple strategy to engineer CBT motif in a tripodal molecule which consists of central spacer and aryl/heteroaryl ring substituted benzimidazolyl cores. ${ }^{8}$ Our earlier studies ${ }^{8}$ reveal that both alkyl group on the central benzene spacer and the aromatic group at 2-position of benzimidazolyl core are necessary to arrange the tripodal molecules with benzimidazolyl based CBT motif. Up to now, furan, thiophene, phenyl, pyridyl, methoxy groups substituted phenyl are used as a steric group at 2-position of benzimidazolyl unit, to force the tripodal molecule to adopt CBT motif. To understand the stability of the CBT motif, we engineered the tripodal molecule by increasing the length of heteroaryl/aryl and alkylthiophene at 2-position of benzimidazolyl unit (Fig. 1).

Herein, a series of 2-substituted bithiophene, biphenyl and alkylthiophene benzimidazoles $\left(\mathrm{L}^{1}-\mathrm{L}^{4}\right)$ and tripodal molecules 1a-4b were prepared and characterized by elemental analysis, high-resolution mass spectrometry (HR-MS) and NMR spectroscopic methods. Though there are experimental and theoretical works on cooperative interactions, quantitative intramolecular cooperativity measurements are scarce in the literature. ${ }^{\mathbf{9 - 1 7}}$ Therefore, theoretically, it is challenging and interesting to come up with a scheme to partition the CBT motifs to calculate the intramolecular interactions and to correlate with experimental relative NMR chemical shifts. 


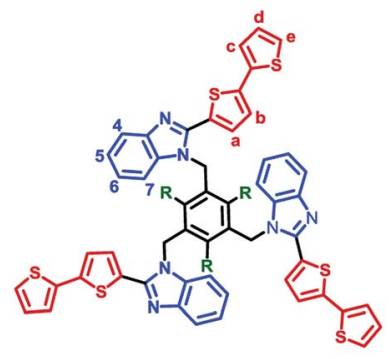

1a, $\mathrm{R}=\mathrm{CH}_{3} ; \mathbf{1 b}, \mathrm{R}=\mathrm{CH}_{2} \mathrm{CH}_{3}$

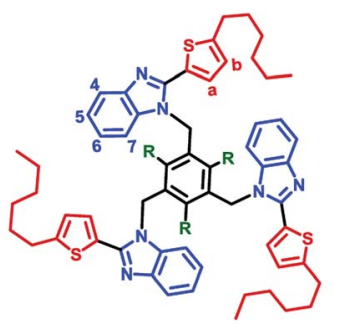

3a, $\mathrm{R}=\mathrm{CH}_{3} ; 3 \mathbf{b}, \mathrm{R}=\mathrm{CH}_{2} \mathrm{CH}_{3}$

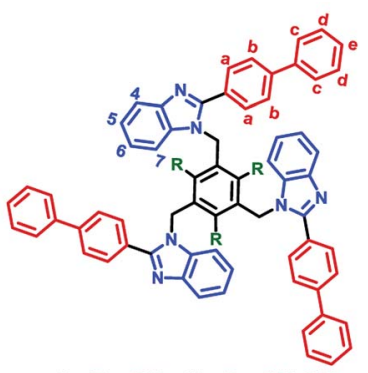

$2 \mathrm{a}, \mathrm{R}=\mathrm{CH}_{3} ; \mathbf{2 b}, \mathrm{R}=\mathrm{CH}_{2} \mathrm{CH}_{3}$

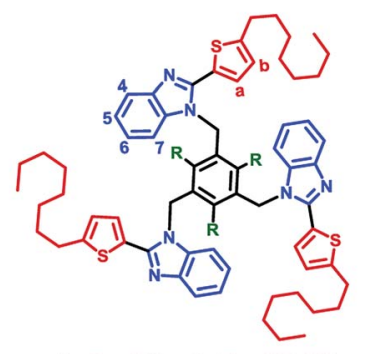

$4 \mathrm{a}, \mathrm{R}=\mathrm{CH}_{3} ; 4 \mathrm{~b}, \mathrm{R}=\mathrm{CH}_{2} \mathrm{CH}_{3}$

Fig. 1 Tripodal molecules $1 a-4 b$.

\section{Results and discussion}

\section{Preparations}

2-(2,2'-Bithiophen-5-yl)benzimidazole ( $\left.\mathrm{L}^{1}\right), 2$-(1,1'-biphenyl-4-yl) benzimidazole $\left(\mathrm{L}^{2}\right), 2-\left(5\right.$-hexylthiophen-2-yl)benzimidazole $\left(\mathrm{L}^{3}\right)$ and 2-(5-octylthiophen-2-yl)benzimidazole $\left(\mathrm{L}^{4}\right)$ were synthesized by the reaction of $o$-phenylenediamine with corresponding aldehydes. ${ }^{8 c}$ Subsequent treatment of $\mathrm{L}^{n}$ with 1,3,5tris(bromomethyl)mesitylene or 1,3,5-tris(bromomethyl)-2,4,6triethylbenzene in THF by using $\mathrm{NaH}$ as base yield tripodal molecules 1a-4b. All the benzimidazoles and the tripodal molecules $(\mathbf{1} \mathbf{a}-\mathbf{4 b})$ are air and moisture stable and soluble in organic solvents. Elemental analysis, HR-MS and NMR spectroscopic methods were used for characterizing the molecules. All the ligands and the tripodal molecules display molecular ion peaks $\left(\mathrm{m} / \mathrm{z}\right.$ for $\left.[\mathbf{M}+\mathbf{H}]^{+}\right)$those match the theoretical values (vide infra experimental section).

\section{NMR studies}

NMR spectra of $\mathrm{L}^{1}-\mathrm{L}^{4}$ and $\mathbf{1 a}-\mathbf{4} \mathbf{b}$ were recorded in $d_{6}$-DMSO solvent (Fig. S7-S32 in ESI $†$ ). Molecule 1a displays a single set of chemical resonances for all protons. A new peak at $\delta 5.6 \mathrm{ppm}$ and 6:27 methylene: aromatic protons ratio confirms the formation of 1a (Fig. 2). The chemical resonances for $\mathrm{H}^{6}$ and $\mathrm{H}^{7}$ protons of benzimidazolyl were significantly upfield shifted compare to those in $\mathrm{L}^{1}$ (Fig. 2 and 3). $\mathrm{H}^{4}$ and $\mathrm{H}^{5}$ protons of benzimidazolyl and bithiophene protons $\left(\mathrm{H}^{\mathrm{a}}-\mathrm{H}^{\mathrm{e}}\right)$ either remain in the same position or downfield shifted relative to $\mathrm{L}^{1}$. These data reveal that 1a adopts a syn-conformer with strong CBT motif with three benzimidazolyl units, and all bithiophene units are pointing away from each other. The NMR spectrum of ethyl substituted molecule $\mathbf{1 b}$ shows a similar pattern like that of 1a, except for $\mathrm{H}^{6}$ and $\mathrm{H}^{7}$ protons, which are broad and upfield

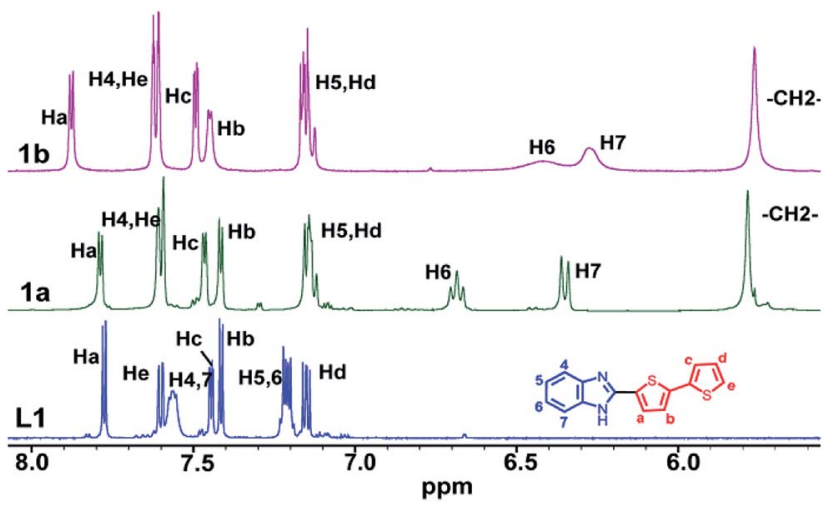

Fig. 2 Partial ${ }^{1} \mathrm{H}$ NMR spectra of $L^{1}, 1 a$ and $1 b$ in $d_{6}$-DMSO solvent.

shifted compared to 1a (Fig. 2). This data indicates that $\mathbf{1 b}$ has a stronger CBT motif compared to $1 \mathbf{1 a}^{\mathbf{8}}$

The ${ }^{1} \mathrm{H}$ NMR spectrum of molecule 2a showed no significant shift for $\mathrm{H}^{4}$ and $\mathrm{H}^{5}$ protons of benzimidazolyl, whereas, $\mathrm{H}^{6}$ and $\mathrm{H}^{7}$ displayed an upfield shift compared to those in $\mathrm{L}^{2}$ (Fig. $\mathrm{S} 1$ in ESI $\dagger)$. The biphenyl protons $\left(\mathrm{H}^{\mathrm{b}}-\mathrm{H}^{\mathrm{e}}\right)$ of $2 \mathrm{a}$ displayed no significant shift compared to $\mathrm{L}^{2}$. Thus, 2a adopt a strong CBT motif with syn-conformation similar to 1a. The ${ }^{1} \mathrm{H}$ NMR spectrum of molecule $2 \mathbf{b}$ displays similar pattern as in $\mathbf{2 a}$, except $\mathrm{H}^{6}$ and $\mathrm{H}^{7}$ protons of benzimidazolyl unit. Latter showed an upfield shift of $\delta 0.73 \mathrm{ppm}$ and $\delta 1.25 \mathrm{ppm}$ relative to $\mathrm{L}^{2}$, respectively (Fig. 3). This data indicates that $\mathbf{2 b}$ also adopt a syn-conformation, but a stronger CBT motif than 2a. Molecules 3 and 4, possessing alkylthiophene units display ${ }^{1} \mathrm{H}$ NMR pattern similar to those of 1-2 (Fig. S3 and S4 in ESI $\dagger$ ).

${ }^{1} \mathrm{H}$ NMR data indicate that modulating five-membered heteroaryl units to six-membered aromatic or alkyl substituted fivemembered heteroaryl at 2-position of benzimidazolyl unit does not alter the strength of edge-to-face interactions (CBT motif) in the tripodal molecules (Fig. S4 and S5 in ESI $\dagger$ ). ${ }^{8}$ This data supports that increasing the length of alkyl chain on thiophene at 2-position of benzimidazolyl unit does not influence the nature of edge-to-face $\mathrm{C}-\mathrm{H} \cdots \pi$ interactions in the CBT motif as observed in previously studied molecules. ${ }^{8 c}$ However, alkyl substituted molecules (3-4) possess stronger CBT motif than aryl substituted molecules (1-2).

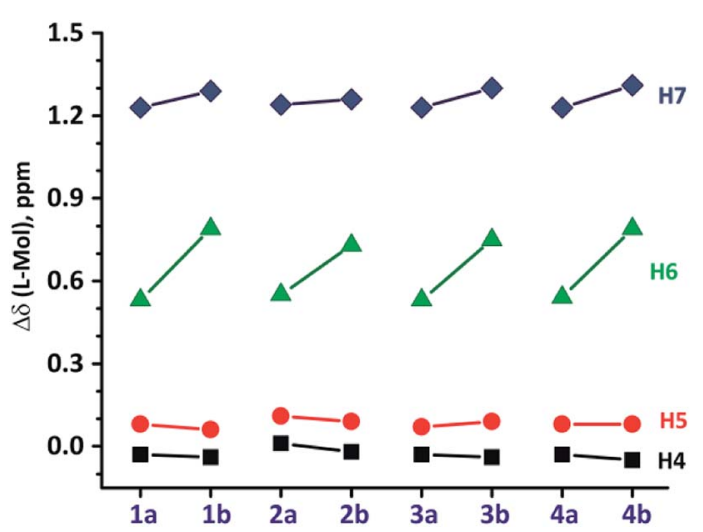

Fig. 3 The relative ${ }^{1} \mathrm{H}$-NMR chemical shift (in ppm) of $\mathrm{H}^{4}-\mathrm{H}^{7}$ protons $\left(\mathrm{Mol}=1 \mathrm{a}-4 \mathrm{~b}\right.$ and $\left.\mathrm{L}=\mathrm{L}^{1}-\mathrm{L}^{4}\right)$. 

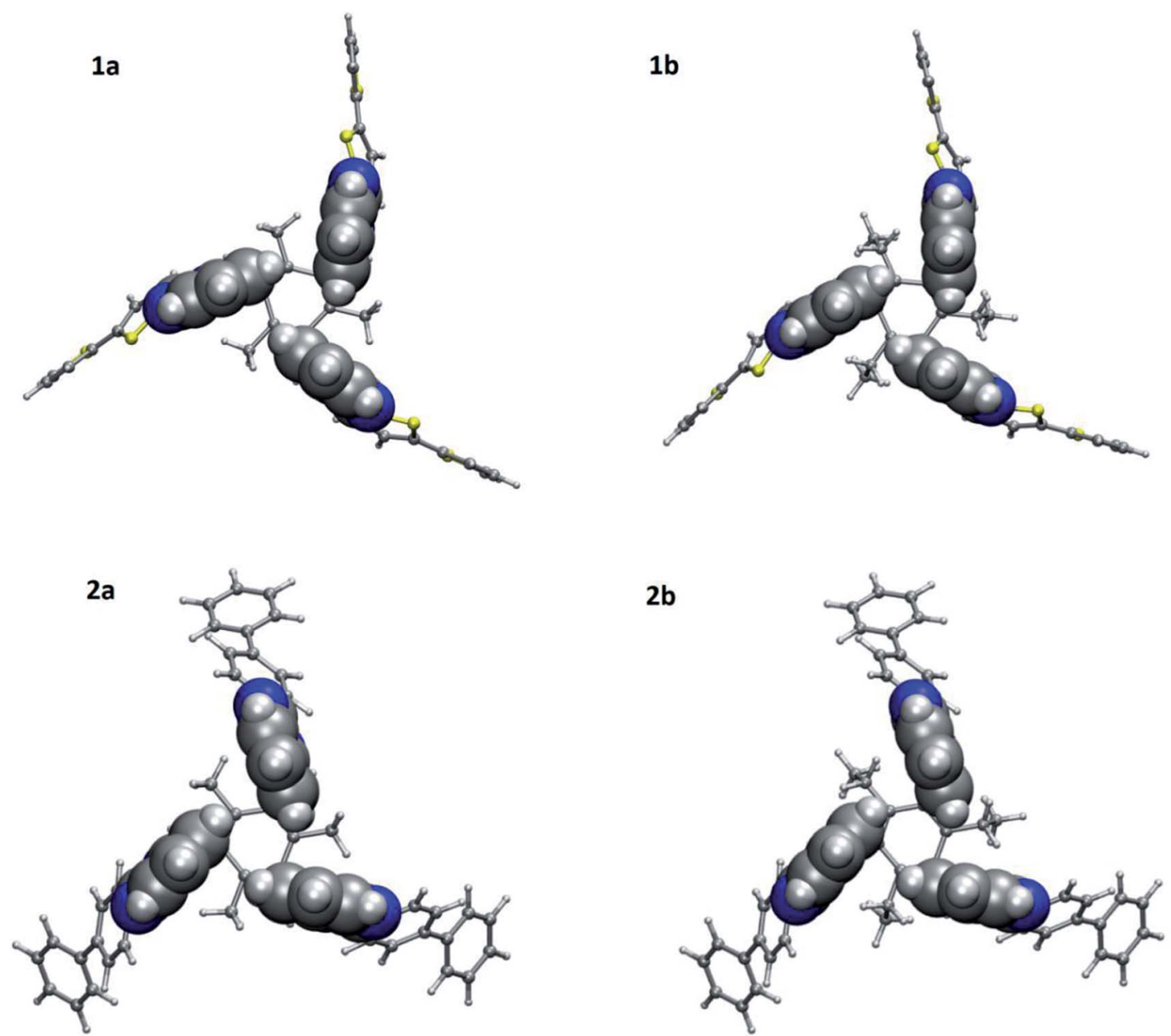

Fig. 4 Molecular structures of 1a, 1b, 2a and 2b evaluated at MPW1PW91/6-311+G(d,p) level of theory and basis function showing the cyclic benzene trimer (CBT) between three benzene rings of benzimidazolyl units.

\section{Molecular modelling}

To further understand the geometry as well as intramolecular interactions for $\mathbf{1 a - 1 b}$ and $\mathbf{2} \mathbf{a}-\mathbf{2} \mathbf{b}$, DFT calculations were performed with Gaussian09 suite of packages ${ }^{18}$ at MPW1PW91/6$311 \mathrm{G}(\mathrm{d}, \mathrm{p})$ level of theory and basis function. All four molecules adopt an edge-to-face syn-conformation, i.e., CBT motif with three benzene rings of benzimidazolyl units (Fig. 4). The geometrical distance between $\mathrm{H}^{7}$ to the center of benzene ring in benzimidazolyl unit is shorter in ethyl substituted molecules (3.55 $\AA$ for $\mathbf{1 b}$ and $3.53 \AA$ for $2 \mathbf{b}$ ) compared to methyl substituted (3.66 Å for 1a and $3.60 \AA$ for $2 \mathrm{a}$ ) molecules.

We have followed the scheme depicted in Fig. S6 in ESI $\dagger$ for calculating the intramolecular $\mathrm{C}-\mathrm{H} \cdots \pi$ interaction energies, ${ }^{19}$ performed with the optimized geometries at MPW1PW91/6$311 \mathrm{G}(\mathrm{d}, \mathrm{p})$. The calculated intramolecular energies at M062X/6$311+\mathrm{G}(\mathrm{d}, \mathrm{p})$ [MPW1PW91/6-311+G(d,p)] levels of theory and basis function are reported in Table 1 . The calculated intramolecular $\mathrm{C}-\mathrm{H} \cdots \pi$ interaction energy between benzene $\mathrm{C}-\mathrm{H}$ with neighboring benzene $\pi$-electron cloud in the CBT core indicates that the intramolecular interaction energy is higher for ethyl substituted molecules (1b and $\mathbf{2 b}$ ) than methyl substituted ones (1a and 2a).

The relative magnitude of the NMR chemical shift of $\mathbf{1 a}, \mathbf{1} \mathbf{b}$, 2a and $\mathbf{2 b}$ in DMSO solvent were calculated relative to the ligands $\left(\mathrm{L}^{1}\right.$ and $\mathrm{L}^{2}$ ) using SMD solvent model ${ }^{20}$ (Table 2). The $\mathrm{H}^{6}$ and $\mathrm{H}^{7}$ protons of benzimidazolyl unit shows a higher upfield

Table 1 Fragment energies, total energy (Hartrees) and intramolecular energies (kcal mol ${ }^{-1}$ ) at M062X [MPW1PW91]/6-311+G(d,p) levels of theory and basis function calculated for $1 a, 1 b, 2 a$ and $2 b$, as per the scheme depicted in Fig. S6 in ESI

\begin{tabular}{lllllr}
\hline Mol & $F_{1}$ & $F_{2}$ & $F_{3}$ & $E_{\text {Total }}$ & $E_{3 F_{1}-3 F_{2}+F_{3}}$ \\
\hline 1a & -3392.63315 & -1871.33900 & -350.04673 & -4913.92920 & -4913.92731 \\
1b & -3510.52082 & -1989.22580 & -467.93282 & -5031.81789 & -5031.81585 \\
2a & -2109.61118 & -1229.82792 & -350.046850 & -2989.39661 & -2989.39443 \\
2b & -2227.49869 & -1347.71468 & -467.93286 & -3107.28491 & -3107.28271
\end{tabular}


Table 2 Experimental and theoretical [MPW1PW91/6-311+G(d,p)] relative ${ }^{1} \mathrm{H}$ chemical shift (in ppm) of $1 \mathrm{a}, 1 \mathrm{~b}, 2 \mathrm{a}$ and $2 \mathrm{~b}$ with the corresponding ligand $\left(L^{1}-L^{2}\right)$ in $d_{6}$-DMSO solvent

\begin{tabular}{|c|c|c|c|c|c|c|c|c|c|}
\hline Mol & $\mathrm{H}^{4}$ & $\mathrm{H}^{5}$ & $\mathrm{H}^{6}$ & $\mathrm{H}^{7}$ & $\mathrm{H}^{\mathrm{a}}$ & $\mathrm{H}^{\mathrm{b}}$ & $\mathrm{H}^{\mathrm{c}}$ & $\mathrm{H}^{\mathrm{d}}$ & $\mathrm{H}^{\mathrm{e}}$ \\
\hline $1 a$ & $-0.03[-0.02]$ & $0.08[0.01]$ & $0.53[0.79]$ & $1.22[1.25]$ & $0.00[0.05]$ & $0.00[-0.11]$ & $-0.02[-0.05]$ & $0.08[-0.02]$ & $0.00[0.02]$ \\
\hline $1 b$ & $-0.04[-0.01]$ & $0.06[0.06]$ & $0.79[1.04]$ & $1.29[1.42]$ & $-0.09[0.00]$ & $-0.03[-0.13]$ & $-0.05[-0.05]$ & $0.07[-0.02]$ & $-0.01[0.02]$ \\
\hline $2 b$ & $-0.02[0.00]$ & $0.09[0.07]$ & $0.73[1.16]$ & $1.26[1.53]$ & $0.38[0.20]$ & $0.06[-0.09]$ & $0.02[-0.06]$ & $0.00[0.05]$ & $-0.01[-0.04]$ \\
\hline
\end{tabular}

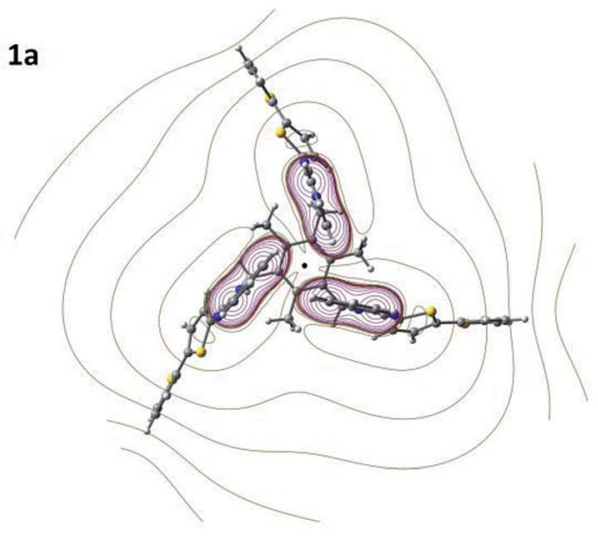

$2 a$

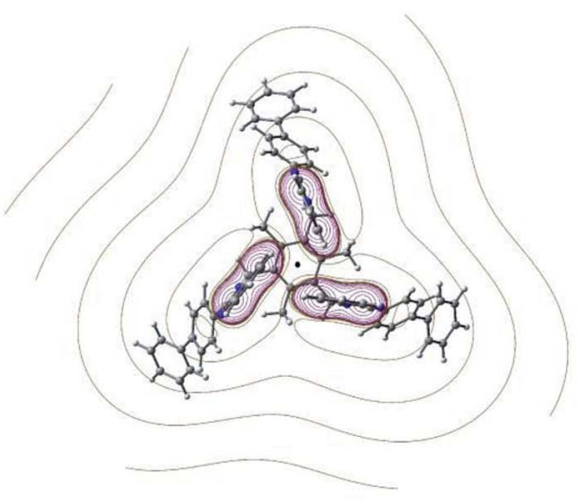

1b

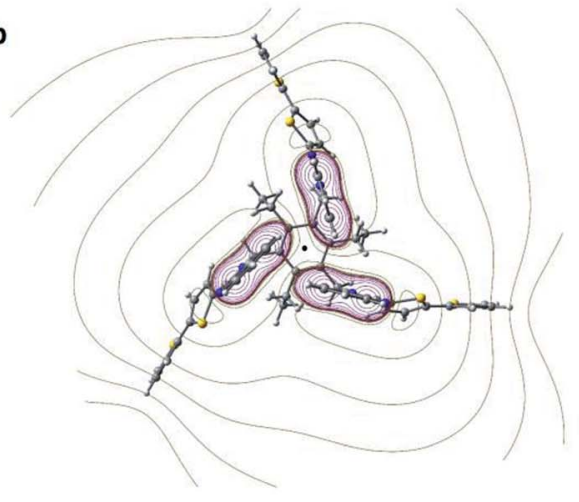

$2 b$

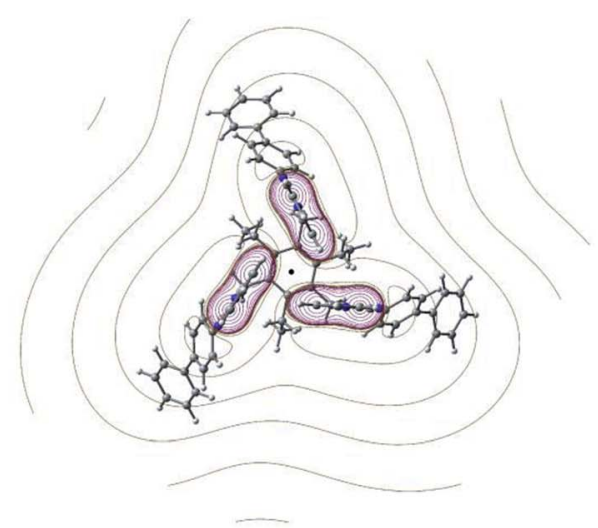

Fig. 5 MESP topography distribution of $1 a, 1 b, 2 a$ and $2 b$ evaluated at MPW1PW91/6-311+G(d,p) level of theory and basis set. The consecutive contours are separated by 0.02 a.u.

shift, while the remaining $\mathrm{H}^{4}-\mathrm{H}^{5}$ protons and $\mathrm{H}^{\mathrm{a}}-\mathrm{H}^{\mathrm{e}}$ protons of bithiophene/biphenyl unit are unaffected on the formation of the cyclic-trimer motifs (Table 2). The theoretical results corroborated well with the experiment. To justify the relative NMR chemical shift and to quantify the cooperative $\mathrm{C}-\mathrm{H} \cdots \pi$ interaction, the molecular electrostatic potential (MESP) topography is calculated ${ }^{21}$ and is defined at a point $r$, as the amount of energy required to bring a unit positive charge from infinity to that point. ${ }^{22-24}$ MESP contours in the plane passing through the center of the benzene rings are depicted in Fig. 5 . The $(3,+3)$ MESP critical point at the center of the cyclic trimer ring indicates the formation of CBT motif in $\mathbf{1 a}, \mathbf{1 b}, \mathbf{2 a}$, and $\mathbf{2 b}$. The MESP minimum is more negative for ethyl substituted molecules $(-0.024$ a.u for $\mathbf{1 b}$ and -0.030 a.u. for $\mathbf{2 b})$ than methyl substituted ones $(-0.020$ a.u for $1 \mathrm{a}$ and -0.027 a.u. for 2a). An increase in the negative value of the MESP value within the benzene trimer motifs shows an increase in the electronic contribution in this region. Also, the magnitude of the MESP $(3,+3) \mathrm{CP}$ indicates the formation of a stable intramolecular CBT motif.

\section{Conclusions}

Bithiophene, biphenyl, alkylthiophene based benzimidazoles $\left(\mathrm{L}^{1}-\mathrm{L}^{4}\right)$, new tripodal molecules (1-4) possessing these benzimidazolyl units and benzene spacer with methyl/ethyl group were prepared and characterized. These molecules adopt a strong CBT motif in solution. A stronger edge-to-face intramolecular $\mathrm{C}-\mathrm{H} \cdots \pi$ interactions is observed in ethyl substituted molecules (1)-4b) than the corresponding methyl ones (1a-4a) in solution. A similar formation of strong CBT motif stabilized by cooperative edge-to-face interactions in molecules (1-2) in 
DMSO solution is observed by using DFT calculations. Also, the formation of CBT is explained by intramolecular cooperative energy, relative ${ }^{1} \mathrm{H}$ NMR chemical shift and $(3,+3)$ critical point in MESP topology in molecules (1-2). The results indicate that increasing the length of aromatic units or alkyl chain on thiophene and benzene group at 2-position of benzimidazolyl unit is not enough to break the CBT motif, stabilized by the cooperative edge-to-face $\mathrm{C}-\mathrm{H} \cdots \pi$ interactions, in solution. Therefore, this quantitative study may facilitate crystal engineering of molecules with CBT motifs for desired properties.

\section{Experimental section}

\section{General experimental methods}

Biphenyl-4-carboxaldehyde, $\mathrm{NaHSO}_{3}, \quad o$-phenylenediamine, $\mathrm{NaH}, \quad$ 1,3,5-tris(bromomethyl)mesitylene and 1,3,5tris(bromomethyl)-2,4,6-triethyl- benzene were purchased from commercial sources and used as received. 2,2'-Bithiophene-5carboxaldehyde, 5-hexylthiophene-2-carboxaldehyde, and 5octylthiophene-2-carboxaldehyde were prepared from previously reported methods. ${ }^{25}$ All solvents were purchased from commercial sources and distilled prior to use. All reactions were carried out in an inert atmosphere. NMR spectra were recorded on Bruker Avance III 400 and $500 \mathrm{MHz}$ instruments. The chemical shifts $(\delta)$ were reported in parts per million (ppm) relative to the residual solvent signal. HR-MS were recorded on a Bruker maXis mass spectrometer. Elemental analysis was performed on a Flash EA series 1112 CHNS analyzer.

General procedure for the synthesis of ligands $\left(L^{1}-L^{4}\right)$. A stirred solution of $o$-phenylenediamine ( 1 equiv.), aldehyde (1 equiv.) and $\mathrm{NaHSO}_{3}$ (3 equiv.) in DMF were heated at $80{ }^{\circ} \mathrm{C}$ for 7-8 h. The progress of the reaction was monitored by TLC. After completion of reaction, the crude mixture was poured into icecold water. The precipitated solid was filtered, washed with water and dried under vacuum to get crude product.

2-(2,2'-Bithiophen-5-yl)benzimidazole $\left(\mathbf{L}^{\mathbf{1}}\right)$. Orange solid product $(1.8 \mathrm{~g}, 93 \%)$ was prepared from 2,2'-bithiophene-5carboxaldehyde $(1.37 \mathrm{~g}, 7.05 \mathrm{mmol}), o$-phenylenediamine (762 mg, $7.05 \mathrm{mmol}$ ) and $\mathrm{NaHSO}_{3}\left(2.21 \mathrm{~g}, 21.15 \mathrm{mmol}\right.$ ). ${ }^{1} \mathrm{H}$ NMR (500 MHz, $d_{6}$-DMSO, ppm): $\delta 13.04(1 \mathrm{H}, \mathrm{br}, \mathrm{NH}), 7.78\left(1 \mathrm{H}, \mathrm{d}, J_{\mathrm{HH}}\right.$ $\left.=3.9 \mathrm{~Hz}, \mathrm{H}^{\mathrm{a}}\right), 7.60\left(1 \mathrm{H}, \mathrm{dd}, J_{\mathrm{HH}}=5.0,1.1 \mathrm{~Hz}, \mathrm{H}^{\mathrm{e}}\right), 7.57(2 \mathrm{H}, \mathrm{q}$, $\left.J_{\mathrm{HH}}=3.0 \mathrm{~Hz}, \mathrm{H}^{4,7}\right), 7.44\left(1 \mathrm{H}, \mathrm{dd}, J_{\mathrm{HH}}=3.5,1.1 \mathrm{~Hz}, \mathrm{H}^{\mathrm{c}}\right), 7.41(1 \mathrm{H}$, $\left.\mathrm{d}, J_{\mathrm{HH}}=3.8 \mathrm{~Hz}, \mathrm{H}^{\mathrm{b}}\right), 7.21\left(2 \mathrm{H}, \mathrm{q}, J_{\mathrm{HH}}=3.0 \mathrm{~Hz}, \mathrm{H}^{5,6}\right)$ and 7.15 $\left(1 \mathrm{H}, \mathrm{dd}, J_{\mathrm{HH}}=3.6,1.4 \mathrm{~Hz}, \mathrm{H}^{\mathrm{d}}\right) .{ }^{13} \mathrm{C}$ NMR $\left(125 \mathrm{MHz}, d_{6}-\mathrm{DMSO}\right.$, ppm): $\delta 146.93,139.14,136.34,132.44,129.03,128.15,126.82$, 125.44, 125.31 and 122.86 (aromatic and bithiophene). HR-MS $(\mathrm{m} / \mathrm{z})$ : calc. for $\mathrm{C}_{15} \mathrm{H}_{11} \mathrm{~N}_{2} \mathrm{~S}_{2}(\mathrm{M}+\mathrm{H})^{+}$: 283.0364; found, 283.0363. Anal. calc. for $\mathrm{C}_{15} \mathrm{H}_{10} \mathrm{~N}_{2} \mathrm{~S}_{2}$ : C, 63.80; H, 3.57; N, 9.92; $\mathrm{S}$, 22.71 found: C, 63.71; H, 3.51; N, 10.07; S, 22.71.

2-(1,1'-Biphenyl-4-yl)benzimidazole $\left(\mathrm{L}^{2}\right)$. White solid product $(2.3 \mathrm{~g}, 92 \%)$ was prepared from biphenyl-4-carboxaldehyde (1.69 g, $9.25 \mathrm{mmol})$, o-phenylenediamine (1.0 g, $9.25 \mathrm{mmol})$ and $\mathrm{NaHSO}_{3}(2.89 \mathrm{~g}, 27.75 \mathrm{mmol}) .{ }^{1} \mathrm{H}$ NMR $\left(500 \mathrm{MHz}, d_{6}\right.$ DMSO, ppm): $\delta 8.28\left(2 \mathrm{H}, \mathrm{dt}, J_{\mathrm{HH}}=8.5,1.8 \mathrm{~Hz}, \mathrm{H}^{\mathrm{a}}\right), 7.88(2 \mathrm{H}, \mathrm{dt}$, $\left.J_{\mathrm{HH}}=8.5,1.8 \mathrm{~Hz}, \mathrm{H}^{\mathrm{b}}\right), 7.78\left(2 \mathrm{H}, \mathrm{dd}, J_{\mathrm{HH}}=7.2,1.2 \mathrm{~Hz}, \mathrm{H}^{\mathrm{c}}\right), 7.63$ $\left(2 \mathrm{H}, \mathrm{q}, J_{\mathrm{HH}}=3.0 \mathrm{~Hz}, \mathrm{H}^{4,7}\right), 7.51\left(2 \mathrm{H}, \mathrm{t}, J_{\mathrm{HH}}=7.4 \mathrm{~Hz}, \mathrm{H}^{\mathrm{d}}\right), 7.42$ $\left(1 \mathrm{H}, \mathrm{t}, J_{\mathrm{HH}}=7.3 \mathrm{~Hz}, \mathrm{H}^{\mathrm{e}}\right), 7.23\left(2 \mathrm{H}, \mathrm{q}, J_{\mathrm{HH}}=3.0 \mathrm{~Hz}, \mathrm{H}^{5,6}\right) .{ }^{13} \mathrm{C}$
NMR (100 MHz, $d_{6}$-DMSO, ppm): $\delta$ 151.36, 141.83, 139.70, $129.52,129.43,128.46,128.40,127.64,127.51,127.17$ and 122.72 (aromatic and biphenyl). HR-MS $(\mathrm{m} / \mathrm{z})$ : calc. for $\mathrm{C}_{19} \mathrm{H}_{15} \mathrm{~N}_{2}$ $(\mathrm{M}+\mathrm{H})^{+}$: 271.1235; found 271.1239. Anal. calc. for $\mathrm{C}_{19} \mathrm{H}_{14} \mathrm{~N}_{2}: \mathrm{C}$, 84.42; H, 5.22; N, 10.36 found: C, 84.32; H, 5.15, N, 10.36 .

2-(5-Hexylthiophen-2-yl)benzimidazole $\left(\mathbf{L}^{3}\right)$. Yellow solid product $(2.6 \mathrm{~g}, 98 \%)$ was prepared from 5-hexylthiophene-2carboxaldehyde (1.81 g, $9.23 \mathrm{mmol}), o$-phenylenediamine $(1.0 \mathrm{~g}, 9.25 \mathrm{mmol})$ and $\mathrm{NaHSO}_{3}(2.88 \mathrm{~g}, 27.67 \mathrm{mmol}) .{ }^{1} \mathrm{H} \mathrm{NMR}$ (500 MHz, $d_{6}$-DMSO, ppm): $\delta 12.82(1 \mathrm{H}$, br s, NH), $7.63(1 \mathrm{H}, \mathrm{d}$, $\left.J_{\mathrm{HH}}=3.6 \mathrm{~Hz}, \mathrm{H}^{\mathrm{a}}\right), 7.52\left(2 \mathrm{H}\right.$, br s, $\left.\mathrm{H}^{4,7}\right), 7.17\left(2 \mathrm{H}, \mathrm{q}, J_{\mathrm{HH}}=3.0 \mathrm{~Hz}\right.$, $\left.\mathrm{H}^{5,6}\right), 6.94\left(1 \mathrm{H}, \mathrm{d}, J_{\mathrm{HH}}=3.6 \mathrm{~Hz}, \mathrm{H}^{\mathrm{b}}\right), 2.83\left(2 \mathrm{H}, \mathrm{t}, J_{\mathrm{HH}}=7.5 \mathrm{~Hz}\right.$, thio- $\left.\mathrm{CH}_{2}-\right)$, $1.68-1.62\left(2 \mathrm{H}\right.$, quint, $J_{\mathrm{HH}}=7.4 \mathrm{~Hz}$, thio- $\left.\mathrm{C}-\mathrm{CH}_{2}-\right)$, 1.36-1.25 (6H, m, $\left.-\left(\mathrm{CH}_{2}\right)_{3}{ }^{-}\right), 0.87\left(3 \mathrm{H}, \mathrm{t}, J_{\mathrm{HH}}=7.05 \mathrm{~Hz},-\mathrm{C}-\mathrm{CH}_{3}\right)$. ${ }^{13} \mathrm{C}$ NMR (100 MHz, $\left.\mathrm{CDCl}_{3}, \mathrm{ppm}\right): \delta$ 149.65, 148.07, 138.94, $130.25,127.18,125.28,122.73,114.84$ (aromatic and thiophene), 31.50, 31.40, 30.19, 28.67, 22.54 and 14.06 (hexyl). HRMS $(m / z)$ : calc. for $\mathrm{C}_{17} \mathrm{H}_{21} \mathrm{~N}_{2} \mathrm{~S}(\mathrm{M}+\mathrm{H})^{+}$: 285.1425, found, 285.1429. Anal. calc. for $\mathrm{C}_{17} \mathrm{H}_{20} \mathrm{~N}_{2} \mathrm{~S}$ : C, 71.79; H, 7.09; N, 9.85; S, 11.27 found: C, 71.68; H, 7.15; N, 9.76; S, 11.41 .

2-(5-Octylthiophen-2-yl)benzimidazole $\left(\mathbf{L}^{\mathbf{4}}\right)$. Yellow solid product $(2.1 \mathrm{~g}, 85 \%)$ was prepared from 5-octylthiophene-2carboxaldehyde $(1.80 \mathrm{~g}, \quad 8.0 \mathrm{mmol}), o$-phenylenediamine (865 mg, $8.0 \mathrm{mmol}$ ) and $\mathrm{NaHSO}_{3}(2.5 \mathrm{~g}, 24.0 \mathrm{mmol}) .{ }^{1} \mathrm{H} \mathrm{NMR}$ (500 MHz, $d_{6}$-DMSO, ppm): $\delta 12.83(1 \mathrm{H}, \mathrm{br}, \mathrm{NH}), 7.64\left(1 \mathrm{H}, \mathrm{d}, J_{\mathrm{HH}}\right.$ $\left.=3.7 \mathrm{~Hz}, \mathrm{H}^{\mathrm{a}}\right), 7.52\left(2 \mathrm{H}\right.$, br s, $\left.\mathrm{H}^{4,7}\right), 7.17\left(2 \mathrm{H}, \mathrm{q}, J_{\mathrm{HH}}=3.0 \mathrm{~Hz}\right.$, $\left.\mathrm{H}^{5,6}\right), 6.94\left(1 \mathrm{H}, \mathrm{d}, J_{\mathrm{HH}}=3.7 \mathrm{~Hz}, \mathrm{H}^{\mathrm{b}}\right), 2.83\left(2 \mathrm{H}, \mathrm{t}, J_{\mathrm{HH}}=7.5 \mathrm{~Hz}\right.$, thio- $\left.\mathrm{CH}_{2}-\right), 1.65\left(2 \mathrm{H}\right.$, quint, $J_{\mathrm{HH}}=7.4 \mathrm{~Hz}$, thio-C- $\left.\mathrm{CH}_{2}-\right)$, 1.36$1.25\left(10 \mathrm{H}, \mathrm{m},-\left(\mathrm{CH}_{2}\right)_{5}-\right), 0.85\left(3 \mathrm{H}, \mathrm{t}, J_{\mathrm{HH}}=7.0 \mathrm{~Hz},-\mathrm{CH}_{3}\right) .{ }^{13} \mathrm{C}$ NMR (100 MHz, $\mathrm{CDCl}_{3}$, ppm): $\delta 149.71,147.71,130.21,126.67$, 125.21, 122.81 (aromatic and thiophene), 31.84, 31.48, 30.22, 29.29, 29.20, 29.04, 22.65, 14.10 (octyl). HR-MS ( $\mathrm{m} / \mathrm{z}$ ): calc. for $\mathrm{C}_{19} \mathrm{H}_{25} \mathrm{~N}_{2} \mathrm{~S}(\mathrm{M}+\mathrm{H})^{+}$: 313.1728; found, 313.1736. Anal. calc. for $\mathrm{C}_{19} \mathrm{H}_{24} \mathrm{~N}_{2} \mathrm{~S}: \mathrm{C}, 73.03 ; \mathrm{H}, 7.74 ; \mathrm{N}, 8.97 ; \mathrm{S}, 10.26$ found: $\mathrm{C}, 73.15 ; \mathrm{H}$, 7.68; N, 8.89; S, 10.28 .

General procedure for the synthesis of tripodal molecules (1-4). To a stirred solution of ligand $\left(\mathrm{L}^{1}-\mathrm{L}^{4}\right)$ in $\mathrm{THF}$ at $0{ }^{\circ} \mathrm{C}, \mathrm{NaH}$ (1.2 equiv.) was added and allowed to stir at room temperature for $1 \mathrm{~h}$. To this solution, solid tribromo compound(s) were added and stirring continued. The progress of the reaction was monitored by TLC. After completion of reaction, the solvent was removed under reduced pressure and ice water was added to the resulting mixture. The precipitated solid was collected by filtration under vacuum, washed with hexane and air dried.

1,3,5-Tris(2-(2,2'-bithiophen-5-yl)benzimidazol-1-ylmethyl)2,4,6-trimethylbenzene (1a). Yellow solid product (436 mg, 87\%) was prepared from $\mathrm{L}^{1}$ (424 mg, $1.5 \mathrm{mmol}$ ), $\mathrm{NaH}$ (45 mg, 2.0 $\mathrm{mmol}$ ) and 1,3,5-tris(bromomethyl)mesitylene (200 $\mathrm{mg}, 0.5$ mmol). ${ }^{1} \mathrm{H} \mathrm{NMR}\left(400 \mathrm{MHz}, d_{6}\right.$-DMSO, ppm): $\delta 7.78\left(3 \mathrm{H}, \mathrm{d}, J_{\mathrm{HH}}=\right.$ $\left.3.9 \mathrm{~Hz}, \mathrm{H}^{\mathrm{a}}\right), 7.60\left(6 \mathrm{H}, \mathrm{d}, J_{\mathrm{HH}}=6.3 \mathrm{~Hz}, \mathrm{H}^{4} \& \mathrm{H}^{\mathrm{e}}\right), 7.46\left(3 \mathrm{H}, \mathrm{d}, J_{\mathrm{HH}}\right.$ $\left.=3.5 \mathrm{~Hz}, \mathrm{H}^{\mathrm{c}}\right), 7.41\left(3 \mathrm{H}, \mathrm{d}, J_{\mathrm{HH}}=3.8 \mathrm{~Hz}, \mathrm{H}^{\mathrm{b}}\right), 7.15-7.11(6 \mathrm{H}, \mathrm{m}$, $\left.\mathrm{H}^{5} \& \mathrm{H}^{\mathrm{d}}\right), 6.68\left(3 \mathrm{H}, \mathrm{t}, J_{\mathrm{HH}}=7.7 \mathrm{~Hz}, \mathrm{H}^{6}\right), 6.35\left(3 \mathrm{H}, \mathrm{d}, J_{\mathrm{HH}}=8.3 \mathrm{~Hz}\right.$, $\left.\mathrm{H}^{7}\right) 5.78\left(6 \mathrm{H}, \mathrm{s},-\mathrm{CH}_{2}-\right)$ and $2.05\left(9 \mathrm{H}, \mathrm{s},-\mathrm{CH}_{3}\right) .{ }^{13} \mathrm{C}$ NMR (100 MHz, $d_{6}$-DMSO, ppm): $\delta 147.72,143.17,139.96,138.95,136.06$, 136.52, 131.58, 131.24, 130.70, 129.04, 126.98, 125.65, 125.20, $123.15,122.40,119.58,111.68$ (aromatic and bithiophene), $46.56\left(-\mathrm{CH}_{2}-\right)$ and $16.84\left(-\mathrm{CH}_{3}\right)$. HR-MS $(\mathrm{m} / \mathrm{z})$ : calc. for 
$\mathrm{C}_{57} \mathrm{H}_{43} \mathrm{~N}_{6} \mathrm{~S}_{6}(\mathrm{M}+\mathrm{H})^{+}$: 1003.1873; found 1003.1873. Anal. calc. for $\mathrm{C}_{57} \mathrm{H}_{42} \mathrm{~N}_{6} \mathrm{~S}_{6}$ : C, 68.23; H, 4.22; N, 8.38; S, 19.17 found: $\mathrm{C}$, 68.36; H, 4.26, N, 8.27, S, 19.05.

1,3,5-Tris(2-(2,2'-bithiophen-5-yl)benzimidazol-1-ylmethyl)2,4,6-triethylbenzene (1b). Yellow solid product (492 mg, 83\%) was prepared from $\mathrm{L}^{1}$ (480 mg, $1.7 \mathrm{mmol}$ ), $\mathrm{NaH}(52 \mathrm{mg}, 2.1$ mmol) and 1,3,5-tris(bromomethyl)-2,4,6-triethylbenzene (250 mg, $0.56 \mathrm{mmol}$ ). ${ }^{1} \mathrm{H}$ NMR (400 MHz, $d_{6}$-DMSO, ppm): $\delta 7.87\left(3 \mathrm{H}, \mathrm{d}, J_{\mathrm{HH}}=3.9 \mathrm{~Hz}, \mathrm{H}^{\mathrm{a}}\right), 7.61\left(6 \mathrm{H}, \mathrm{dd}, J_{\mathrm{HH}}=5.2,1.3 \mathrm{~Hz}\right.$, $\left.\mathrm{H}^{4} \& \mathrm{H}^{\mathrm{e}}\right), 7.49\left(3 \mathrm{H}, \mathrm{dd}, J_{\mathrm{HH}}=3.6,1.2 \mathrm{~Hz}, \mathrm{H}^{\mathrm{c}}\right), 7.44\left(3 \mathrm{H}, \mathrm{d}, J_{\mathrm{HH}}=\right.$ $\left.3.4 \mathrm{~Hz}, \mathrm{H}^{\mathrm{b}}\right), 7.17-7.12\left(6 \mathrm{H}, \mathrm{m}, \mathrm{H}^{5} \& \mathrm{H}^{\mathrm{d}}\right), 6.42\left(3 \mathrm{H}, \mathrm{br}, \mathrm{H}^{6}\right), 6.28$ $\left(3 \mathrm{H}, \mathrm{br} \mathrm{s}, \mathrm{H}^{7}\right), 5.76\left(6 \mathrm{H}, \mathrm{s},-\mathrm{CH}_{2}-\right), 2.58\left(6 \mathrm{H}, \mathrm{d}, J_{\mathrm{HH}}=6.8 \mathrm{~Hz}\right.$, $\left.-\mathrm{CH}_{2}-\mathrm{CH}_{3}\right)$ and $0.72\left(9 \mathrm{H}, \mathrm{s},-\mathrm{CH}_{2}-\mathrm{CH}_{3}\right) .{ }^{13} \mathrm{C} \mathrm{NMR}\left(125 \mathrm{MHz}, d_{6}-\right.$ DMSO, ppm): $\delta$ 147.64, 145.75, 143.31, 140.07, 136.06, 135.58, 131.06, 130.67, 129.06, 126.99, 125.69, 125.16, 122.98, 122.29, 119.67, 112.28 (aromatic and bithiophene), $45.28\left(-\mathrm{CH}_{2}-\right), 23.55$ $\left(-\mathrm{CH}_{2}-\mathrm{CH}_{3}\right)$ and $14.75\left(-\mathrm{CH}_{2}-\mathrm{CH}_{3}\right)$. HR-MS $(\mathrm{m} / \mathrm{z})$ : calc. for $\mathrm{C}_{60} \mathrm{H}_{49} \mathrm{~N}_{6} \mathrm{~S}_{6}(\mathrm{M}+\mathrm{H})^{+}:$1045.2343; found 1045.2342. Anal. calc. for $\mathrm{C}_{60} \mathrm{H}_{48} \mathrm{~N}_{6} \mathrm{~S}_{6}: \mathrm{C}, 68.93 ; \mathrm{H}, 4.63 ; \mathrm{N}, 8.04 ; \mathrm{S}, 18.40$ found: $\mathrm{C}$, 68.83; H, 4.71; N, 8.12; S, 18.34.

1,3,5-Tris(2-(1,1'-biphenyl-4-yl)benzimidazol-1-ylmethyl)2,4,6-trimethylbenzene (2a). White solid product (214 mg, 89\%) was prepared from $\mathrm{L}^{2}$ (270 mg, $\left.0.75 \mathrm{mmol}\right)$, NaH $(22 \mathrm{mg}, 0.9$ $\mathrm{mmol}$ ) and 1,3,5-tris(bromomethyl)mesitylene (100 mg, 0.25 mmol). ${ }^{1} \mathrm{H}$ NMR (500 MHz, $d_{6}$-DMSO, ppm): $\delta 7.85\left(6 \mathrm{H}, \mathrm{d}, J_{\mathrm{HH}}=\right.$ $\left.8.2 \mathrm{~Hz}, \mathrm{H}^{\mathrm{a}}\right), 7.79\left(6 \mathrm{H}, \mathrm{d}, J_{\mathrm{HH}}=8.2 \mathrm{~Hz}, \mathrm{H}^{\mathrm{b}}\right), 7.74\left(6 \mathrm{H}, \mathrm{d}, J_{\mathrm{HH}}=\right.$ $\left.7.3 \mathrm{~Hz}, \mathrm{H}^{\mathrm{c}}\right), 7.62\left(3 \mathrm{H}, \mathrm{d}, J_{\mathrm{HH}}=8.0 \mathrm{~Hz}, \mathrm{H}^{4}\right), 7.50\left(6 \mathrm{H}, \mathrm{t}, J_{\mathrm{HH}}=\right.$ $\left.7.6 \mathrm{~Hz}, \mathrm{H}^{\mathrm{d}}\right), 7.40\left(3 \mathrm{H}, \mathrm{t}, J_{\mathrm{HH}}=7.3 \mathrm{~Hz}, \mathrm{H}^{\mathrm{e}}\right), 7.12\left(3 \mathrm{H}, \mathrm{t}, J_{\mathrm{HH}}=\right.$ $\left.7.8 \mathrm{~Hz}, \mathrm{H}^{5}\right), 6.68\left(3 \mathrm{H}, \mathrm{t}, J_{\mathrm{HH}}=7.7 \mathrm{~Hz}, \mathrm{H}^{6}\right), 6.39\left(3 \mathrm{H}, \mathrm{d}, J_{\mathrm{HH}}=\right.$ $\left.8.2 \mathrm{~Hz}, \mathrm{H}^{7}\right), 5.56\left(6 \mathrm{H}, \mathrm{s},-\mathrm{CH}_{2}-\right)$ and $1.89\left(9 \mathrm{H}, \mathrm{s},-\mathrm{CH}_{3}\right) .{ }^{13} \mathrm{C} \mathrm{NMR}$ (100 MHz, $d_{6}$-DMSO, ppm): $\delta$ 154.04, 143.22, 141.63, 139.64, 138.40, 135.13, 131.56, 130.68, 129.94, 128.42, 127.24, 127.17, 122.85, 121.97, 119.71, 111.66 (aromatic and biphenyl), 46.25 $\left(-\mathrm{CH}_{2}-\right)$ and $16.81\left(-\mathrm{CH}_{3}\right)$. HR-MS $(\mathrm{m} / \mathrm{z})$ : calc. for $\mathrm{C}_{69} \mathrm{H}_{55} \mathrm{~N}_{6}(\mathrm{M}+$ $\mathrm{H})^{+}$: 967.4488; found, 967.4488. Anal. calc. for $\mathrm{C}_{69} \mathrm{H}_{54} \mathrm{~N}_{6}: \mathrm{C}$, 85.68; H, 5.63; N, 8.69 found: C, 85.49; H, 5.67, N, 8.58.

1,3,5-Tris(2-(1,1'-biphenyl-4-yl)benzimidazol-1-ylmethyl)2,4,6-triethylbenzene (2b). White solid product (661 mg, 96\%) was prepared from $\mathrm{L}^{2}$ (551 mg, $2.04 \mathrm{mmol}$ ), NaH (60 mg, 2.5 $\mathrm{mmol}$ ) and 1,3,5-tris(bromomethyl)-2,4,6-triethylbenzene (300 mg, $0.68 \mathrm{mmol}$ ). ${ }^{1} \mathrm{H}$ NMR (500 MHz, $d_{6}$-DMSO, ppm): $\delta 7.90\left(6 \mathrm{H}, \mathrm{d}, J_{\mathrm{HH}}=8.0 \mathrm{~Hz}, \mathrm{H}^{\mathrm{a}}\right), 7.84-7.80\left(6 \mathrm{H}, \mathrm{m}, \mathrm{H}^{\mathrm{b}}\right), 7.76(6 \mathrm{H}$, $\left.\mathrm{d}, J_{\mathrm{HH}}=7.6 \mathrm{~Hz}, \mathrm{H}^{\mathrm{c}}\right), 7.65\left(3 \mathrm{H}, \mathrm{d}, J_{\mathrm{HH}}=8.0 \mathrm{~Hz}, \mathrm{H}^{4}\right), 7.51(6 \mathrm{H}, \mathrm{t}$, $\left.J_{\mathrm{HH}}=7.5 \mathrm{~Hz}, \mathrm{H}^{\mathrm{d}}\right), 7.44-7.41\left(3 \mathrm{H}, \mathrm{m}, \mathrm{H}^{\mathrm{e}}\right), 7.14\left(3 \mathrm{H}, \mathrm{t}, J_{\mathrm{HH}}=\right.$ $\left.7.5 \mathrm{~Hz}, \mathrm{H}^{5}\right), 6.50\left(3 \mathrm{H}, \mathrm{t}, J_{\mathrm{HH}}=6.0 \mathrm{~Hz}, \mathrm{H}^{6}\right), 6.37\left(3 \mathrm{H}, \mathrm{d}, J_{\mathrm{HH}}=\right.$ $\left.8.0 \mathrm{~Hz}, \mathrm{H}^{7}\right), 5.55\left(6 \mathrm{H}, \mathrm{s},-\mathrm{CH}_{2}-\right), 2.71-2.63\left(6 \mathrm{H}, \mathrm{m},-\mathrm{CH}_{2}-\mathrm{CH}_{3}\right)$ and 0.47 (9H, s, $\left.-\mathrm{CH}_{2}-\mathrm{CH}_{3}\right) .{ }^{13} \mathrm{C} \mathrm{NMR}\left(100 \mathrm{MHz}, \mathrm{CDCl}_{3}, \mathrm{ppm}\right)$ : $\delta 153.74,145.40,143.24,142.74,139.95,134.65,130.69,130.14$, 129.18, 129.01, 128.04, 127.45, 127.38, 127.16, 123.30, 122.23, 120.11, 111.62 (aromatic and biphenyl), $44.97\left(-\mathrm{CH}_{2}^{-}\right), 23.76$ $\left(-\mathrm{CH}_{2}-\mathrm{CH}_{3}\right)$ and $14.48\left(-\mathrm{CH}_{2}-\mathrm{CH}_{3}\right)$. HR-MS $(\mathrm{m} / \mathrm{z})$ : calc. for $\mathrm{C}_{72} \mathrm{H}_{61} \mathrm{~N}_{6}(\mathrm{M}+\mathrm{H})^{+}:$1009.4958; found, 1009.4961. Anal. calc. for $\mathrm{C}_{72} \mathrm{H}_{60} \mathrm{~N}_{6}$ : C, 85.68; H, 8.33; N, 8.33 found: C, 85.76; H, 5.99, N, 8.33.

1,3,5-Tris(2-(5-hexylthiophen-2-yl)benzimidazol-1-ylmethyl)2,4,6-trimethylbenzene (3a). Yellow solid product (209 mg, 83\%) was prepared from $\mathrm{L}^{3}$ (213 mg, $0.75 \mathrm{mmol}$ ), NaH (22 mg, 0.9 $\mathrm{mmol}$ ) and 1,3,5-tris(bromomethyl)mesitylene (100 mg, 0.25 mmol). ${ }^{1} \mathrm{H}$ NMR (500 MHz, $d_{6}$-DMSO, ppm): $\delta 7.62\left(3 \mathrm{H}, \mathrm{d}, J_{\mathrm{HH}}=\right.$ $\left.3.6 \mathrm{~Hz}, \mathrm{H}^{\mathrm{a}}\right), 7.55\left(3 \mathrm{H}, \mathrm{d}, J_{\mathrm{HH}}=8.1 \mathrm{~Hz}, \mathrm{H}^{4}\right), 7.10\left(3 \mathrm{H}, \mathrm{t}, J_{\mathrm{HH}}=\right.$ $\left.7.6 \mathrm{~Hz}, \mathrm{H}^{5}\right), 6.97\left(3 \mathrm{H}, \mathrm{d}, J_{\mathrm{HH}}=3.4 \mathrm{~Hz}, \mathrm{H}^{\mathrm{b}}\right), 6.63\left(3 \mathrm{H}, \mathrm{t}, J_{\mathrm{HH}}=\right.$ $\left.7.6 \mathrm{~Hz}, \mathrm{H}^{6}\right), 6.29\left(3 \mathrm{H}, \mathrm{d}, J_{\mathrm{HH}}=8.2 \mathrm{~Hz}, \mathrm{H}^{7}\right), 5.70\left(6 \mathrm{H}, \mathrm{s},-\mathrm{CH}_{2}-\right)$, $2.85\left(6 \mathrm{H}, \mathrm{t}, J_{\mathrm{HH}}=7.4 \mathrm{~Hz}\right.$, thio- $\left.\mathrm{CH}_{2}-\right), 1.99\left(9 \mathrm{H}, \mathrm{s},-\mathrm{CH}_{3}\right), 1.66$ $\left(6 \mathrm{H}\right.$, quint, $\left.J_{\mathrm{HH}}=7.4 \mathrm{~Hz},-\mathrm{C}-\mathrm{CH}_{2}-\right), 1.35-1.27\left(18 \mathrm{H}, \mathrm{m},-\left(\mathrm{CH}_{2}\right)_{3}-\right.$ ), $0.85\left(9 \mathrm{H}, \mathrm{t}, J_{\mathrm{HH}}=6.8 \mathrm{~Hz},-\mathrm{C}-\mathrm{CH}_{3}\right) \cdot{ }^{13} \mathrm{C} \mathrm{NMR}\left(100 \mathrm{MHz}, \mathrm{CDCl}_{3}\right.$, ppm): $\delta 150.41,148.58,143.26,138.80,134.80,131.19,129.23$, 128.90, 124.96, 122.96, 122.94, 122.27, 119.97, 110.83 (aromatic and thiophene), $46.29\left(-\mathrm{CH}_{2}-\right), 17.01\left(-\mathrm{CH}_{3}\right), 31.54,31.48$, $30.18,28.77,22.57$ and 14.09 (hexyl). HR-MS $(\mathrm{m} / \mathrm{z})$ : calc. for $\mathrm{C}_{63} \mathrm{H}_{73} \mathrm{~N}_{6} \mathrm{~S}_{3}(\mathrm{M}+\mathrm{H})^{+}:$1009.5059; found, 1009.5054. Anal. calc. for $\mathrm{C}_{63} \mathrm{H}_{72} \mathrm{~N}_{6} \mathrm{~S}_{3}$ : C, 74.96; H, 7.19; N, 8.33; S, 9.53 found C, 74.89; $\mathrm{H}, 7.15 ; \mathrm{N}, 8.26$; S, 9.70.

1,3,5-Tris(2-(5-hexylthiophen-2-yl)benzimidazol-1-ylmethyl)2,4,6-triethylbenzene (3b). Yellow solid product (421 mg, 88\%) was prepared from $\mathrm{L}^{3}$ (387 mg, $1.36 \mathrm{mmol}$ ), NaH (40 mg, 1.7 $\mathrm{mmol}$ ) and 1,3,5-tris(bromomethyl)-2,4,6-triethylbenzene (200 mg, $0.45 \mathrm{mmol}) .{ }^{1} \mathrm{H}$ NMR (500 MHz, $d_{6}$-DMSO, ppm): $\delta 7.69\left(3 \mathrm{H}, \mathrm{d}, J_{\mathrm{HH}}=3.2 \mathrm{~Hz}, \mathrm{H}^{\mathrm{a}}\right), 7.56\left(3 \mathrm{H}, \mathrm{t}, J_{\mathrm{HH}}=6.8 \mathrm{~Hz}, \mathrm{H}^{4}\right)$, $7.08\left(3 \mathrm{H}\right.$, quint, $\left.J_{\mathrm{HH}}=6.9 \mathrm{~Hz}, \mathrm{H}^{5}\right), 7.00\left(3 \mathrm{H}, \mathrm{s}, \mathrm{H}^{\mathrm{b}}\right), 6.45-6.39$ $\left(3 \mathrm{H}, \mathrm{m}, \mathrm{H}^{6}\right), 6.24-6.20\left(3 \mathrm{H}, \mathrm{m}, \mathrm{H}^{7}\right), 5.67\left(6 \mathrm{H}, \mathrm{s},-\mathrm{CH}_{2}-\right), 2.87(6 \mathrm{H}$, $\mathrm{t}, J_{\mathrm{HH}}=7.2 \mathrm{~Hz}$, thio- $\left.\mathrm{CH}_{2}-\right), 2.46\left(6 \mathrm{H}, \mathrm{d}, J_{\mathrm{HH}}=1.8 \mathrm{~Hz},-\mathrm{CH}_{2}-\right.$ $\left.\mathrm{CH}_{3}\right), 1.72-1.63\left(6 \mathrm{H}, \mathrm{m},-\mathrm{C}-\mathrm{CH}_{2}-\right), 1.39-1.27\left(18 \mathrm{H}, \mathrm{m},-\left(\mathrm{CH}_{2}\right)_{3}-\right)$ and $0.86-0.83\left(18 \mathrm{H}, \mathrm{m},-\mathrm{CH}_{2}-\mathrm{CH}_{3}\right.$ and $\left.-\mathrm{C}-\mathrm{CH}_{3}\right) .{ }^{13} \mathrm{C}$ NMR (100 $\left.\mathrm{MHz}, \mathrm{CDCl}_{3}, \mathrm{ppm}\right): \delta 150.30,148.26,145.77,143.28,134.91$, 130.62, 129.08, 128.92, 124.92, 123.16, 122.21, 119.94, 114.54 (aromatic and thiophene), $44.83\left(-\mathrm{CH}_{2}-\right), 23.75\left(-\mathrm{CH}_{2}-\mathrm{CH}_{3}\right)$, $14.59\left(-\mathrm{CH}_{2}-\mathrm{CH}_{3}\right), 31.53,30.16,28.6,22.57$, and 14.08 (hexyl). HR-MS $(m / z)$ : calc. for $\mathrm{C}_{66} \mathrm{H}_{79} \mathrm{~N}_{6} \mathrm{~S}_{3}(\mathrm{M}+\mathrm{H})^{+}$: 1051.5528; found, 1051.5525. Anal. calc. for $\mathrm{C}_{66} \mathrm{H}_{78} \mathrm{~N}_{6} \mathrm{~S}_{3}: \mathrm{C}, 75.38 ; \mathrm{H}, 7.48 ; \mathrm{N}, 7.99$; S, 9.15 found C, 75.29; H, 7.56; N, 7.91; S, 9.24.

1,3,5-Tris(2-(5-octylthiophen-2-yl)benzimidazol-1-ylmethyl)2,4,6-trimethylbenzene (4a). Yellow solid product (486 mg, 89\%) was prepared from $\mathrm{L}^{4}$ (470 mg, $1.504 \mathrm{mmol}$ ), NaH (43 mg, 1.8 $\mathrm{mmol}$ ) and 1,3,5-tris(bromomethyl)mesitylene (200 $\mathrm{mg}, 0.501$ mmol). ${ }^{1} \mathrm{H}$ NMR (500 MHz, $d_{6}$-DMSO, ppm): $\delta 7.60\left(3 \mathrm{H}, \mathrm{s}, \mathrm{H}^{\mathrm{a}}\right)$, $7.55\left(3 \mathrm{H}, \mathrm{d}, J_{\mathrm{HH}}=7.6 \mathrm{~Hz}, \mathrm{H}^{4}\right), 7.09\left(3 \mathrm{H}, \mathrm{t}, J_{\mathrm{HH}}=6.8 \mathrm{~Hz}, \mathrm{H}^{5}\right), 6.95$ $\left(3 \mathrm{H}, \mathrm{s}, \mathrm{H}^{\mathrm{b}}\right), 6.63\left(3 \mathrm{H}, \mathrm{t}, J_{\mathrm{HH}}=7.6 \mathrm{~Hz}, \mathrm{H}^{6}\right), 6.29\left(3 \mathrm{H}, \mathrm{d}, J_{\mathrm{HH}}=\right.$ $\left.7.6 \mathrm{~Hz}, \mathrm{H}^{7}\right), 5.69\left(6 \mathrm{H}, \mathrm{s},-\mathrm{CH}_{2}-\right), 2.83\left(6 \mathrm{H}, \mathrm{s}\right.$, thio- $\left.\mathrm{CH}_{2}-\right), 1.98$ $\left(9 \mathrm{H}, \mathrm{s},-\mathrm{CH}_{3}\right), 1.65\left(6 \mathrm{H}, \mathrm{s},-\mathrm{C}-\mathrm{CH}_{2}-\right), 1.29-1.22\left(30 \mathrm{H}, \mathrm{m},-\left(\mathrm{CH}_{2}\right)_{5}-\right.$ ), 0.83 (9H, s, $\left.-\mathrm{CH}_{3}\right) .{ }^{13} \mathrm{C}$ NMR (100 MHz, $d_{6}$-DMSO, ppm): $\delta 149.52,148.39,143.09,138.76,135.16,131.16,131.44,129.78$, $129.70,125.79,122.81,122.06,119.35,111.44$ (aromatic and thiophene), $46.37\left(-\mathrm{CH}_{2}-\right), 16.78\left(-\mathrm{CH}_{3}\right), 31.74,31.49,29.85$, 29.17, 29.11, 28.96, 22.56 and 14.36 (octyl). HR-MS ( $\mathrm{m} / \mathrm{z}$ ): calc. for $\mathrm{C}_{69} \mathrm{H}_{85} \mathrm{~N}_{6} \mathrm{~S}_{3}(\mathrm{M}+\mathrm{H})^{+}$: 1093.5998; found, 1093.5991. Anal. calc. for $\mathrm{C}_{69} \mathrm{H}_{84} \mathrm{~N}_{6} \mathrm{~S}_{3}: \mathrm{C}, 75.78 ; \mathrm{H}, 7.74 ; \mathrm{N}, 7.68 ; \mathrm{S}, 8.79$ found $\mathrm{C}$, 75.86; H, 7.68; N, 7.75; S, 8.71.

1,3,5-Tris(2-(5-octylthiophen-2-yl)benzimidazol-1-ylmethyl)2,4,6-triethylbenzene (4b). Yellow solid product (427 mg, 83\%) was prepared from $\mathrm{L}^{4}$ (425 mg, $1.36 \mathrm{mmol}$ ), NaH (40 mg, 1.7 $\mathrm{mmol}$ ) and 1,3,5-tris(bromomethyl)-2,4,6-triethylbenzene (200 mg, $0.45 \mathrm{mmol}) .{ }^{1} \mathrm{H}$ NMR (500 MHz, $d_{6}$-DMSO, ppm): $\delta 7.67\left(3 \mathrm{H}, \mathrm{d}, J_{\mathrm{HH}}=3.4 \mathrm{~Hz}, \mathrm{H}^{\mathrm{a}}\right), 7.57\left(3 \mathrm{H}, \mathrm{d}, J_{\mathrm{HH}}=8.0 \mathrm{~Hz}, \mathrm{H}^{4}\right)$, $7.09\left(3 \mathrm{H}, \mathrm{t}, J_{\mathrm{HH}}=7.5 \mathrm{~Hz}, \mathrm{H}^{5}\right), 6.99\left(3 \mathrm{H}, \mathrm{s}, \mathrm{H}^{\mathrm{b}}\right), 6.40-6.35(3 \mathrm{H}$, 
br s, $\left.\mathrm{H}^{6}\right), 6.21\left(3 \mathrm{H}, \mathrm{s}, \mathrm{H}^{7}\right), 5.67\left(6 \mathrm{H}, \mathrm{s},-\mathrm{CH}_{2}-\right), 2.87\left(6 \mathrm{H}, \mathrm{t}, J_{\mathrm{HH}}=\right.$ $7.1 \mathrm{~Hz}$, thio- $\left.\mathrm{CH}_{2}-\right), 2.49\left(6 \mathrm{H}, \mathrm{s},-\mathrm{CH}_{2}-\mathrm{CH}_{3}\right), 1.67\left(6 \mathrm{H}, \mathrm{t}, J_{\mathrm{HH}}=\right.$ $\left.6.7 \mathrm{~Hz},-\mathrm{C}-\mathrm{CH}_{2}-\right), 1.30-1.23\left(30 \mathrm{H}, \mathrm{m},-\left(\mathrm{CH}_{2}\right)_{5}{ }^{-}\right), 0.82\left(9 \mathrm{H}, \mathrm{t}, J_{\mathrm{HH}}\right.$ $\left.=5.5 \mathrm{~Hz},-\mathrm{CH}_{3}\right), 0.79-0.72\left(9 \mathrm{H}, \mathrm{m},-\mathrm{CH}_{2}-\mathrm{CH}_{3}\right) .{ }^{13} \mathrm{C} \mathrm{NMR}(100$ $\left.\mathrm{MHz}, \mathrm{CDCl}_{3}, \mathrm{ppm}\right): \delta 150.31,148.26,145.76,143.76,143.28$, 134.91, 130.63, 129.09, 128.91, 124.92, 123.16, 122.21, 119.94, 111.94 (aromatic and thiophene), $44.83\left(-\mathrm{CH}_{2}-\right), 23.78\left(-\mathrm{CH}_{2}-\right.$ $\left.\mathrm{CH}_{3}\right), 14.59\left(-\mathrm{CH}_{2}-\mathrm{CH}_{3}\right), 31.85,31.58,30.17,29.22,29.05,22.66$, and 14.11 (octyl). HR-MS $(\mathrm{m} / \mathrm{z})$ : calc. for $\mathrm{C}_{72} \mathrm{H}_{91} \mathrm{~N}_{6} \mathrm{~S}_{3}(\mathrm{M}+\mathrm{H})^{+}$: 1135.6467, found 1135.6458. Anal. calc. for $\mathrm{C}_{72} \mathrm{H}_{90} \mathrm{~N}_{6} \mathrm{~S}_{3}: \mathrm{C}$, 76.14; H, 7.99; N, 7.40; S, 8.47 found $\mathrm{C}, 76.24 ; \mathrm{H}, 7.89 ; \mathrm{N}, 7.32 ; \mathrm{S}$, 8.55 .

DFT calculations. Geometry optimization of $\mathbf{1 a}-\mathbf{1 b}$ and $\mathbf{2 a -}$ 2b structures were performed with Gaussian 09 suite of packages $^{\mathbf{1 8}}$ at MPW1PW91/6-311G(d,p) level of theory and basis set. The stationary points were characterized by the absence of imaginary frequencies in the harmonic normal vibrational mode analysis. The optimized structures at this level of theory and basis are furnished in the Tables S1-S4 in ESI. $\dagger \mathrm{C}-\mathrm{H} \cdots \pi$ intramolecular interaction energy calculations were performed at MPW1PW91 and M06-2X levels of theory with $6-311+\mathrm{G}(\mathrm{d}, \mathrm{p})$ basis function. The relative magnitude of the NMR chemical shift in the presence of DMSO solvent was calculated relative to ligand $\left(\mathrm{L}^{1}-\mathrm{L}^{2}\right)$ evaluated with solvation model based on density (SMD) solvent model ${ }^{20}$ and MPW1PW91 level of theory with 6$311+\mathrm{G}(\mathrm{d}, \mathrm{p})$ basis function in Gaussian 09 suite of packages. ${ }^{18}$ MESP of the 1a-2b molecules were evaluated with Gaussian 09 suite of packages at MPW1PW91/6-311+G(d,p) level of theory and basis set. ${ }^{24}$

\section{Conflicts of interest}

There are no conflicts to declare.

\section{Acknowledgements}

CKK thank UGC-DSKPDF, SDS thank UGC-NRC, and KVJJ thank UGC-FRPS for funding.

\section{References}

1 E. Lanzarotti, R. R. Biekofsky, D. A. Estrin, M. A. Marti and A. G. Turjanski, J. Chem. Inf. Model., 2011, 51, 1623 and references therein.

2 (a) T. P. Sauer and C. D. Sherrill, J. Phys. Chem. A, 2005, 109, 10475; (b) S. R. Gadre, S. D. Yeole and N. Sahu, Chem. Rev., 2014, 114, 12132; (c) A. S. Mahadevi and G. N. Sastry, Chem. Rev., 2016, 116, 2775; (d) C. Janiak, J. Chem. Soc., Dalton Trans., 2000, 3885; (e) M. Nishio, Phys. Chem. Chem. Phys., 2011, 13, 13873; (f) O. Takahashi, Y. Kohno and M. Nishio, Chem. Rev., 2010, 110, 6049.

3 (a) S. Sarkhel and G. R. Desiraju, Proteins: Struct., Funct., Bioinf., 2004, 54, 247; (b) R. N. V. K. Deepak and R. Sankararamakrishnan, Biophys. J., 2016, 110, 1967.

4 (a) C. A. Hunter, Angew. Chem., Int. Ed., 2004, 43, 5310; (b) J. Singh and J. M. Thornton, FEBS Lett., 1985, 191, 1.
5 (a) T. Morimoto, H. Uno and H. Furuta, Angew. Chem., Int. Ed., 2007, 46, 3672; (b) S. Janich, R. Frohlich, A. Wakamiya, S. Yamaguchi and E. U. Wurthwein, Chem.-Eur. J., 2009, 15, 10457.

6 A. S. Mahadevi and G. N. Sastry, Chem. Rev., 2016, 116, 2775. 7 (a) K. Funatsu, A. Kimura, T. Imamura, A. Ichimura and Y. Sasaki, Inorg. Chem., 1997, 36, 1625; (b) M. Sathiyendiran, J. Y. Wu, M. Velayudham, G. H. Lee, S. M. Peng and K. L. Lu, Chem. Commun., 2009, 3795; (c) S. H. Lin, C. I. Yang, T. S. Kuo, M. H. Chiang, K. C. Hsu and K. L. Lu, Dalton Trans., 2012, 41, 1448; (d) J. Zaho, K. Peng, Y. Guo, J. Zhang, S. Chen and J. Hu, New J. Chem., 2015, 39, 6016.

8 (a) P. Elumalai, P. Rajakannu, F. Hussain and M. Sathiyendiran, RSC Adv., 2013, 3, 2171; (b) S. D. Sathiyashivan, B. Shankar, P. Rajakannu, P. Vishnoi, D. T. Masram and M. Sathiyendiran, $R S C A d v$., 2015, 5, 74705; (c) S. D. Sathiyashivan, C. K. Kumar, B. Shankar, M. Sathiyendiran and D. T. Masram, RSC Adv., 2017, 7, 17297.

9 R. Ludwig, F. Weinhold and T. C. Farrar, J. Phys. Chem. A, 1997, 101, 8861.

10 A. S. Mahadevi, A. Rahalkar, S. R. Gadre and G. N. Sastry, J. Chem. Phys., 2010, 133, 164308.

11 R. Wieczorek and J. J. Dannenberg, J. Am. Chem. Soc., 2004, 126, 14198.

12 T. van Mourik and A. J. Dingley, J. Phys. Chem. A, 2007, 111, 11350.

13 R. D. Parra, S. Bulusu and X. C. Zeng, J. Chem. Phys., 2005, $122,184325$.

14 P. Salvador, N. Kobko, R. Wieczorek and J. J. Dannenberg, J. Am. Chem. Soc., 2004, 126, 14190.

15 K. Ohno, M. Okimura, N. Akai and Y. Katsumoto, Phys. Chem. Chem. Phys., 2005, 7, 3005.

16 S. S. Xantheas, Chem. Phys., 2000, 258, 225.

17 S. Shimizu and H. S. Chan, Proteins: Struct., Funct., Bioinf., 2002, 48, 15.

18 M. J. Frisch, G. W. Trucks, H. B. Schlegel, G. E. Scuseria, M. A. Robb, J. R. Cheeseman, G. Scalmani, V. Barone, B. Mennucci, G. A. Petersson, H. Nakatsuji, M. Caricato, X. Li, H. P. Hratchian, A. F. Izmaylov, J. Bloino, G. Zheng, J. L. Sonnenberg, M. Hada, M. Ehara, K. Toyota, R. Fukuda, J. Hasegawa, M. Ishida, T. Nakajima, Y. Honda, O. Kitao, H. Nakai, T. Vreven, J. A. Montgomery Jr, J. E. Peralta, F. Ogliaro, M. Bearpark, J. J. Heyd, E. Brothers, K. N. Kudin, V. N. Staroverov, R. Kobayashi, J. Normand, K. Raghavachari, A. Rendell, J. C. Burant, S. S. Iyengar, J. Tomasi, M. Cossi, N. Rega, J. M. Millam, M. Klene, J. E. Knox, J. B. Cross, V. Bakken, C. Adamo, J. Jaramillo, R. Gomperts, R. E. Stratmann, O. Yazyev, A. J. Austin, R. Cammi, C. Pomelli, J. W. Ochterski, R. L. Martin, K. Morokuma, V. G. Zakrzewski, G. A. Voth, P. Salvador, J. J. Dannenberg, S. Dapprich, A. D. Daniels, Ö. Farkas, J. B. Foresman, J. V. Ortiz, J. Cioslowski, and D. J. Fox, Gaussian 09, Revision E.01, Gaussian, Inc., Wallingford CT, 2009. 
19 M. M. Deshmukh and S. R. Gadre,J. Phys. Chem. A, 2009, 113, 23 C. H. Suresh and S. R. Gadre, J. Am. Chem. Soc., 1998, 120, 7927. 7049.

20 S. R. Gadre, S. A. Kulkarni and I. H. Shrivastava, J. Chem. 24 A. V. Marenich, C. J. Cramer and D. G. Truhlar, J. Phys. Chem. Phys., 1992, 96, 5253. $B, 2009,113,6378$.

21 Y. Zhao and D. G. Truhlar, J. Chem. Phys., 2006, 125, 194101. 25 (a) Y. Wei, Y. Yang and J.-M. Yeh, Chem. Mater., 1996, 8,

22 S. R. Gadre and I. H. Shrivastava, J. Chem. Phys., 1991, 94, 4384 . 2659; (b) C. Zheng, S. Pu, J. Xu, M. Luo, D. Huang and L. Shen, Tetrahedron, 2007, 63, 5437. 